\title{
Effects of Abamectin on Glutamate Decarboxylase, Alanine Aminotransferase and Aspartate Aminotransferase of Land Snails
}

\author{
Hamza S. A. ${ }^{1}$, Abdelgalil G.M. ${ }^{2}{ }^{*}$, Abdallah E.A.M. ${ }^{3}$, Kassem F.A. ${ }^{3}$ and Asran A.A. ${ }^{2}$ \\ 1National Institute of Oceanography and Fisheries (NIOF), Central Laboratories Unit (CLU), Alexandria, Egypt \\ ${ }^{2}$ Agricultural Research Center (ARC), Plant Protection Research Institute (PPRI), Egypt \\ 3Faculty of Agriculture, Department of Pesticides Chemistry and Technology (Elshatby) Alexandria University, Egypt
}

*Corresponding Author

Received: $20^{\text {th }}$ June, 2020

Accepted: 24th July, 2020

Published online: $1^{\text {st }}$ August, 2020

https://doi.org/10.33745/ijzi.2020.v06i02.010

\begin{abstract}
The objective of this study was to examine the effect of abamectin on glutamate decarboxylase (GAD), alanine aminotransferase (ALT) and aspartate aminotransferase (AST) in land snails, Eobania vermiculata (BGS) and Theba pisana (WGS). We investigated the in vivo effects of abamectin on glutamate decarboxylase (GAD) of snails which was determined by HPLC. Snails (Eobania vermiculata and Theba pisana) were exposed to abamectin at $0.1,0.2$ and 0.5 of $\mathrm{LD}_{50}$ concentrations for 24 and $72 \mathrm{~h}$. The most effective dose of abamectin on GAD activity in both snails was 0.5 of $\mathrm{LD}_{50}$ after 24 and $72 \mathrm{~h}$ which caused maximum elevation of GAD activity. In Eobania vermiculata ALT activity significantly increased with an increase in the abamectin dose. Elevation of ALT activity reached 737 and $750 \%$ at 0.5 of $\mathrm{LD}_{50}$ after 24 and $72 \mathrm{~h}$, respectively, followed by 516 and $567 \%$ activity at 0.2 of $\mathrm{LD}_{50}$ value after 24 and $72 \mathrm{~h}$ and 333 and $400 \%$ at 0.1 of $L D_{50}$ after 24 and $72 \mathrm{~h}$, respectively. In Theba pisana maximum ALT activity was 478 and $500 \%$ at 0.5 of $L D_{50}$ value after 24 and $72 \mathrm{~h}$, respectively. Abamectin at 0.2 of $L D_{50}$ concentration provoked 322 and 333\% ALT activity in Theba pisana after 24 and $72 \mathrm{~h}$ exposure.

Increased AST activity $(\mathrm{n}=5, \mathrm{p}<0.05)$ has been recorded in Eobania vermiculata after abamectin at 0.5 of $\mathrm{LD}_{50}$ concentration after $24(540 \%)$ and $72 \mathrm{~h}(560 \%)$ whereas after 0.2 of $\mathrm{LD}_{50}$ abamectin concentration the AST values at 24 and $72 \mathrm{~h}$ were 400 and $420 \%$ respectively. Abamectin exposure to Eobania vermiculata at 0.1 of $L_{50}$ concentration increased AST activity after $24(340 \%)$ and $72 \mathrm{~h} \mathrm{(360 \% ).} \mathrm{AST} \mathrm{activity} \mathrm{in} \mathrm{Theba} \mathrm{pisana} \mathrm{was} \mathrm{increased}$ by 500 and $580 \%$ after $0.5 \mathrm{LD}_{50}$ abamectin exposure at 24 and $72 \mathrm{~h}$, respectively. The values of AST activity in Theba pisana after 0.2 of $\mathrm{LD}_{50}$ abamectin concentration were 340 and $360 \%$ after 24 and $72 \mathrm{~h}$, respectively whereas after 0.1 of $L_{50}$ abamectin concentration 180 and $190 \%$ after 24 and $72 \mathrm{~h}$, respectively.
\end{abstract}

Keywords: Alanine aminotransferase, Aspartate aminotransferase, Glutamate decarboxylase, Snails, Abamectin, Eobania vermiculata, Theba pisana

Citation: Hamza S.A., Abdelgalil G.M., Abdallah E.A.M., Kassem F.A. and Asran A.A.: Effects of abamectin on glutamate decarboxylase, alanine aminotransferase and aspartate aminotransferase of land snails. Intern. J. Zool. Invest. 6 (2): 311-320, 2020. https://doi.org/10.33745/ijzi.2020.v06i02.010 


\section{Introduction}

Land snails are considered as serious economic pests as they cause damage to several types of plants. These snails attack leaves, flowers, roots, buds, and even the trunk of trees causing great damage to the cultivated plants. In Egypt, terrestrial snails are most dangerous pests to most crops such as field crops, vegetables, ornamental plants and orchards (Kassab and Daoud, 1964; ElOkda, 1979; Abo-Bakr, 1997, 2004; Abdallah et al., 1992, 1998, 2015; Ibrahim, 1995; Mohamed, 1995; Abdelgalil, 2011, 2016, 2018). Damage caused by snails is mainly due to feeding and to contamination with their bodies, faeces or slime, leading to deterioration of the product quality besides, the financial loss (Lglesias et al., 2003). The importance of terrestrial snails, as pests has definitely expanded in the previous decades. (Godan, 1983; Gathwaite and Thomas, 1996).

There are only few pesticides having molluscicidal activity therefore it is needed to search more pesticides having molluscicidal activity. Avermectins are neurotoxins which act through the glutamate or potentially $\gamma$ amino butyric corrosive (GABA)-gated chloride channel (Bai and Ogbourne, 2016). Abamectin, a blend of avermectins, is isolated by fermentation of Streptomyces avermitilis, bacterium (Strong and Brown, 1987; Lasota and Dybas, 1991; Bai and Ogbourne, 2016; He et al., 2009; Khalil and Darwesh, 2019). It acts on the GABA receptor/chloride ionophore complex and glutamate-gated chloride channel (Huang and Casida, 1997; Kane et al., 2000; Hussein and Sabry, 2019). Recently abamectin-based formulations have been studied on antioxidant and detoxifying enzymes in Daphnia magna (Moriena et al., 2020).
In this study the effects of abamectin on glutamate decarboxylase (GAD), alanine transaminase (ALT) and aspartate transaminase (AST) activity of two species of terrestrial snails, brown garden snail (BGS) Eobania vermiculata and white garden snail (WGS) Theba pisana have been studied.

\section{Materials and Methods}

\section{Chemicals:}

Abamectin (avermectin B1a > 80\% and avermectin B1b < 20\%)(95\%) Technical was supplied by Agrochem Co. Egypt. Dimethyl sulfoxide (DMSO), potassium phosphate, Lglutamic acid (L-Glu), pyridoxal 5'-phosphate (PLP), water and methanol (HPLC grade) were supplied by National Institute of Oceanography and Fisheries (NIOF), Central Laboratories Unit (CLU), Alexandria, Egypt. Other chemicals used were analytical grade including sodium acetate, sodium hydroxide, 3-mercaptopropionic acid (3-MPA), ophthaldialdehyde (OPA), boric acid and glacial acetic acid (all from Sigma Chemical Co. St. Louis, MO, USA). Alanine transaminase (ALT) and aspartate transaminase (AST) enzymes were assayed with Diamond Diagnostic kits (Diamond Co. Egypt).

\section{Experimental snails:}

Adults of the brown garden snail, Eobania vermiculata (Müller) and the white garden snail, Theba pisana (Müller) having approximately the same age and size were collected for laboratory experiments. These snails were collected from El-Maamoura garden during spring, Alexandria, Egypt. The snails were transferred to glass boxes (50x30x40 cm) containing $10 \mathrm{~cm}$ soil at the bottom. Boxes were covered with cloth 
netting to prevent snails from escaping. These boxes were maintained under laboratory conditions at $27 \mathrm{C}$ and $65 \%$ R.H. The snails were daily fed on lettuce leaves (Lettuce sativa) and acclimatized to laboratory conditions for 14 days.

Topical application procedure was used according to Abdallah et al. (1992). Abamectin technical was dissolved in dimethyl sulfoxide (DMSO). DMSO has been demonstrated to be the most suitable for topical application as it makes little distress to snails (Young and Wilkins; 1989). Eobania vermiculata (BGS) and Theba pisana (WGS) were exposed to three sub-lethal doses of abamectin at 0.1, 0.2 and 0.5 of $L_{50}$ values for 24 and $72 \mathrm{~h}$. The $\mathrm{LD}_{50}$ values for 24 and $72 \mathrm{~h}$ for Eobania vermiculata were 0.379 and 0.250 and for Theba pisana 0.199 and $0.125 \mu \mathrm{g} / \mathrm{g}$ body weight, respectively ( Abdelgalil et al., 2018). A control group of each species of snails was also run in same laboratory conditions.

Sample preparation:

Abamectin treated and control (untreated) snails of both species were procured after 24 and $72 \mathrm{~h}$. Snail shells were evacuated and the soft bodies were homogenized in 1:10 (w/v) $200 \mathrm{mM}$ potassium phosphate buffer, $\mathrm{pH} 6.8$ utilizing Polytron Kinemetica homogenizer. The homogenate was centrifuged at $5000 \mathrm{rpm}$ for 30 min at $4 \mathrm{C}$ utilizing IEC-CRU 5000 under cooling centrifuge. Supernatant was utilized as the source of enzyme for the determination of enzymes.

Glutamate decarboxylase (GAD) activity:

Enzyme estimation was done by the technique of Allen and Griffiths (1984) with certain modifications. $10 \mu \mathrm{l}$ of source of enzyme, 140 $\mu$ l (200 mM potassium phosphate buffer, $\mathrm{pH}$
6.8), $400 \mu \mathrm{l}(50 \mathrm{mM} \mathrm{L-Glu})$ and $55 \mu \mathrm{l}(0.2 \mathrm{mM}$ pyridoxal 5'- phosphate, PLP) were added. After brooding for $20 \mathrm{~min}$ at $37 \mathrm{C}, 605 \mu \mathrm{l}$ methanol was added at room temperature to end the response and at a similar minute deproteinization operator. The suspension was centrifuged at $1500 \mathrm{rpm}(10 \mathrm{~min}, 0 \mathrm{C})$. Lglutamic acid present in the supernatant was estimated as indicated by Abdelgalil et al. (2018) with certain modifications.

Standard calibration curve for OPAglutamic acid linear response over the concentration range of $0.15,0.3,0.6,1.2$ and $2.4 n$ mole as shown in Figure 1 was determined by applying the similar derivatization procedure. The corresponding optical density was recorded as previously mentioned. Glutamic acid was calculated as $\mu \mathrm{g} / \mathrm{mg}$ protein.

Calculate Limit of Detection (LOD) for each standard by formula: 3.3*standard error/slope.

Calculate of Limit of Quantitation (LOQ) for each standard by formula: 10*standard error/slope.

Alanine transaminase (ALT) and aspartate transaminase (AST) activities:

Alanine transaminase (ALT) and aspartate aminotransferase (AST) were estimated according to the method of Reitman and Frankel (1957). Absorbance was measured at $546 \mathrm{~nm}$.

Statistical analysis:

The data were presented as the mean \pm S.D. Analysis of variance (ANOVA) and differences among the means were determined for significance at 0.05 using (Fisher LSD test) by using the SAS software programme. 


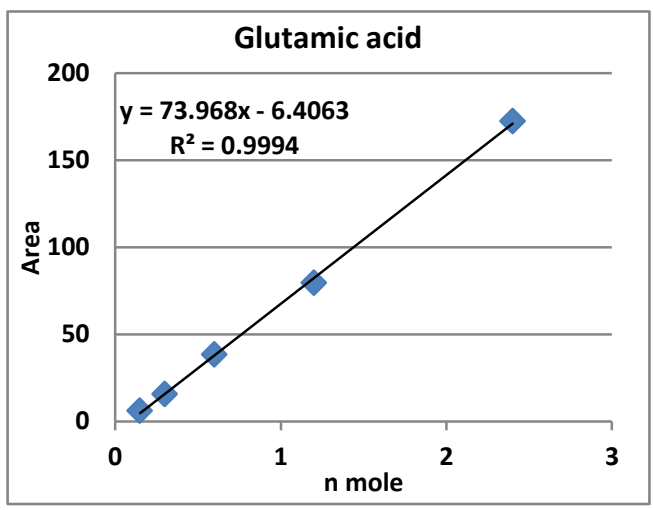

Fig. 1: Standard calibration curve for OPA-glutamic acid linear response over the concentration range of 0.15-2.4 $n$ mole.

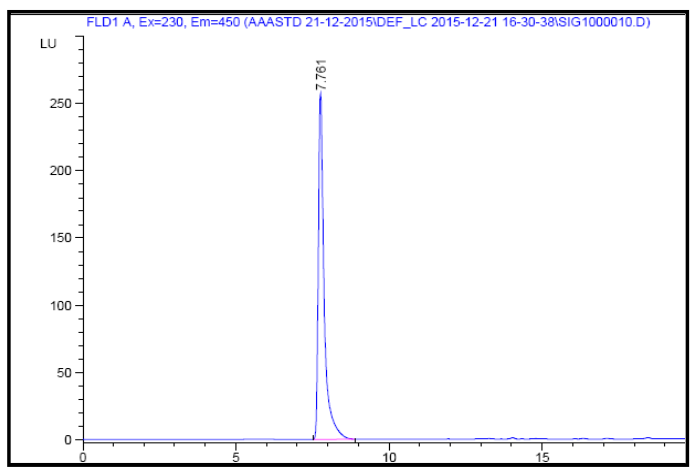

Fig. 2 : Chromatogram illustrating the separation of OPA-derivatized L-glutamic acid (L-GLU).

\section{Results and Discussion}

The effects of abamectin on glutamate decarboxylase activity of snails Eobania vermiculata and Theba pisana have been shown in Table 1 . After $24 \mathrm{~h}$ following abamectin exposure the glutamate decarboxylase activity in Eobania vermiculata was increased which was maximum in 0.5 of $\mathrm{LD}_{50}$ abamectin $(134.50 \%)$ followed by 0.2 of $\mathrm{LD}_{50}$ abamectin (124.9\%) and 0.1 of $\mathrm{LD}_{50}$ abamectin (120.6\%). In Eobania vermiculata the glutamate decarboxylase activities recorded at $72 \mathrm{~h}$ were $147.4 \%$ at 0.5 of $\mathrm{LD}_{50}$ abamectin, $143.4 \%$ at by 0.2 of $L_{50}$ abamectin and $135.6 \%$ at by 0.1 of $L_{50}$ abamectin (Table 1).
In Theba pisana GAD activities noticed after $24 \mathrm{~h}$ were $133.6 \%, 131.4 \%$ and $124.4 \%$ after 0.5 of $\mathrm{LD}_{50}, 0.2$ of $\mathrm{LD}_{50}$ and 0.1 of $\mathrm{LD}_{50}$ abamectin exposure, respectively. After $72 \mathrm{~h}$ following abamectin exposure the glutamate decarboxylase activity in Theba pisana was increased (Table 1) which was maximum in 0.5 of $\mathrm{LD}_{50}$ abamectin $(144.7 \%)$ followed by 0.2 of $\mathrm{LD}_{50}$ abamectin (142.8\%) and 0.1 of $\mathrm{LD}_{50}$ abamectin (135.2\%).

Glutamate decarboxylase (GAD, EC 4.1.2.5) play a significant role in brain excitability through the combination of $\gamma$ aminobuteric acid (GABA), the major inhibitory synapse in the central nervous system (CNS) and is considered as a particular marker for GABAergic neurons and their procedures (Wu et al., 1981; Rossetti and Lombard, 1996).Therefore the evaluation of GAD activity is very important in neurochemical as well as toxicological research (Bedair, 2010). However, GABA has been appeared to evoke both inhibitory and excitatory activities in the central neurons (Walker, 1986, Yarovsky and Carpeneter, 1978) in mollusca -- Limax maxima (Cooke and Gelperin, 1988) and Helix pomatia (Hernadi, 1994). Figure 2 illustrates the chromatogram of the separation of OPA-derivatized L-glutamic acid (L-GLU) which appeared with retention time at 7.76 min. while Figure 3 illustrates chromatogram of the separation of Lglutamic acid derivatives HPLC separation due to abamectin treatments of snails -- (A) Eobania vermiculata and (B) Theba pisana after $24 \mathrm{~h}$ at (0.5 of $\mathrm{LD}_{50}$ value) with retention time at 7.533 and $7.534 \mathrm{~min}$, respectively. The spectrums indicated the same values of retention time as indicated with standard OPA derivatized L-glutamate. 
Table 1: Effects of in vivo abamectin on Eobania vermiculata (BGS) and Theba pisana (WGS) glutamate decarboxylase (GAD) activities

\begin{tabular}{|c|c|c|c|c|c|c|}
\hline & \multicolumn{3}{|c|}{ Eobania vermiculata } & \multicolumn{3}{|c|}{ Theba pisana } \\
\hline Exposure time & $\begin{array}{c}\text { Sub- } \\
\text { lethal } \\
\text { Doses } \\
\mu \mathrm{g} / \mathrm{g} \text { b.w. } \\
\end{array}$ & $\begin{array}{l}\text { Specific activity (nM } \\
\text { glutamic/mg } \\
\text { protein } / \mathrm{min}) \pm \mathrm{SD}\end{array}$ & $\begin{array}{c}\text { Activity } \\
\%\end{array}$ & $\begin{array}{c}\text { Sub- } \\
\text { lethal } \\
\text { Doses } \\
\mu \mathrm{g} / \mathrm{g} \text { b.w. } \\
\end{array}$ & $\begin{array}{l}\text { Specific activity (nM } \\
\text { glutamic/ mg } \\
\text { protein } / \mathrm{min}) \pm \mathrm{SD}\end{array}$ & $\begin{array}{c}\text { Activity } \\
\%\end{array}$ \\
\hline \multirow{3}{*}{$24 \mathrm{~h}$} & 0.1 & $7.34 \pm 0.11$ & 120.6 & 0.1 & $6.99 \pm 0.22$ & 124.4 \\
\hline & 0.2 & $7.61 \pm 0.20$ & 124.9 & 0.2 & $7.385 \pm 0.100$ & 131.4 \\
\hline & 0.5 & $8.18 \pm 0.030$ & 134.5 & 0.5 & $7.505 \pm 0.10$ & 133.6 \\
\hline \multicolumn{2}{|c|}{$\operatorname{LSD}_{0.05}$} & \multicolumn{2}{|l|}{0.226} & & \multicolumn{2}{|l|}{0.255} \\
\hline \multirow{3}{*}{$72 \mathrm{~h}$} & 0.1 & $8.25 \pm 0.05$ & 135.6 & 0.1 & $7.599 \pm 0.104$ & 135.2 \\
\hline & 0.2 & $8.72 \pm 0.11$ & 143.4 & 0.2 & $8.022 \pm 0.054$ & 142.8 \\
\hline & 0.5 & $8.97 \pm 0.09$ & 147.4 & 0.5 & $8.129 \pm 0.105$ & 144.7 \\
\hline \multicolumn{2}{|c|}{$\operatorname{LSD}_{0.05}$} & \multicolumn{2}{|l|}{0.146} & & \multicolumn{2}{|l|}{0.155} \\
\hline
\end{tabular}

Specific activity of untreated snail (GAD) $6.086 \pm 0.0211$ and $5.619 \pm 0.046$ (nM glutamic/ $\mathrm{mg}$ protein $/ \mathrm{min}$ ) $\pm \mathrm{SD}$ for Eobania vermiculata and Theba pisana, respectively, $n=5$ animals; $\mathrm{LSD}_{0.05}$ (least significance difference test at $5 \%$ ); b. w. (body weight)

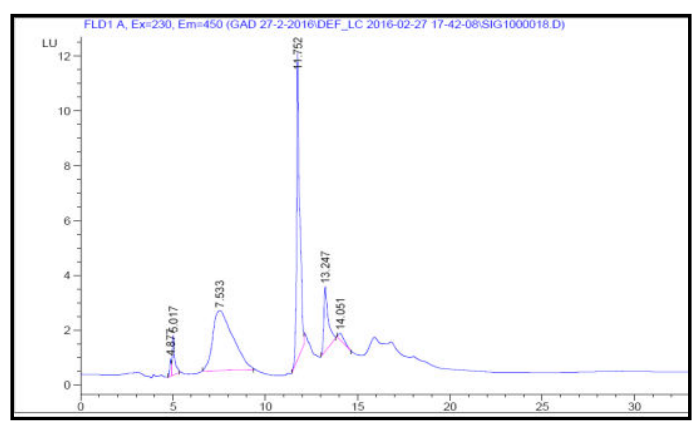

Time (min.)

(A)

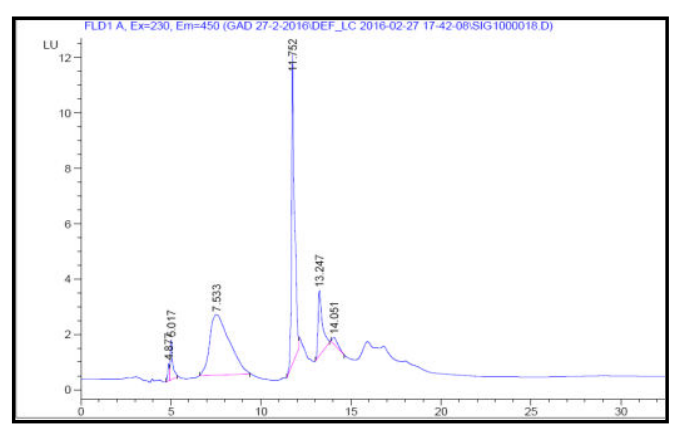

Time (min.)

(B)

Fig. 3: Chromatogram illustrating the separation of L-glutamic acid derivatives HPLC separation due to abamectin treatments after $24 \mathrm{~h}$ at 0.5 of $\mathrm{LD}_{50}$ value). (A) Eobania vermiculata (BGS); (B) Theba pisana (WGS), with retention time at 7.533 and $7.534 \mathrm{~min}$, respectively. The spectrums indicated the same values of retention time as indicated with standard OPA derivatized L-glutamate.

The mechanism by which avermectins caliginosa) as result of treatment with produce the pesticide is the release of $\gamma^{-}$ivermectin. Yamazaki et al. (1989) reported aminobutyric acid (GABA) and the that ivermectin is an agonist for the improvement of its inhibitory action GABA synapse. In this way, the binding of observed that GABA concentrations were ivermectin to a neuronal membrane elevate elevated in earthworm, (Allolobophora the release of GABA which binds to the 
GABA-receptor-chloride channel complex of postsynaptic neuronal membranes causing hyperpolarization of neuronal membrane causing influx of chloride ions, Therefore, it mediates a flaccid paralysis in nematodes and arthropods.

Kass et al. (1980, 1984) used Ascaris lumbricoides as a model system and reported that avermectins function as a GABA agonist which stimulates GABA release from pre-synaptic inhibitory membranes. Abou-Taleb et al. (2009) reported that emamectin benzoate increased the GABA neurotransmitter and glutamic acid concentrations in the field strain of cotton leaf worm to lesser extent than in the laboratory strain. GABA and glutamic acid augmentation are dependant on the emamectin benzoate concentration and the time of exposure. The results of the present study are in agreement with observations of Bedair (2010) and Abdelgalil (2011, 2016, 2018).

The launch of ivermectin in the mid 1980s brought a revolution in the control of animal parasites and was accepted as a potent anthelmintic (Campbell and Benz, 1984). Also, avermectins have wide application as pesticides and antiparasitic drugs for humans and animals (Burg et al., 1979; Ostlind and Long, 1979; Campbell, 1989). The most extensively used compounds of this class are avermectin B1 (abamectin). Abamectin were effectively used for control of the ectoparasite sea lice, the cause of serious problem for the salmon (Salmo salar) in aquaculture industry (Westcott et al., 2004). Campbell (1989) stated that the mechanism by which avermectins produce the pesticide and antiparasitic effects in invertebrates and a neurotoxic effect in vertebrates, is the release of $\gamma$-aminobutyric acid (GABA) and the enhancement of its inhibitory action. Yamazaki et al. (1989) reported that ivermectin is an agonist for the GABA neurotransmitter.

Toxicants are transported by hemocytes to the hepatopancreas through various routes. The damage of liver, the metabolic center for detoxification of synthetics, is affirmed by changes in the activities of alanine aminotransferase (ALT) and aspartate aminotransferase (AST). The activities of such markers show the metabolic changes under the impact of stress. Changes in the degrees of these enzymes in serum are really the most important signal of liver toxicity (Abdelmonem, 2016).

In Eobania vermiculata ALT activity significantly increased with an increase in the abamectin dose. Elevation of ALT activity reached 737 and $750 \%$ at 0.5 of $L_{50}$ after 24 and $72 \mathrm{~h}$, respectively, followed by 516 and $567 \%$ activity at 0.2 of $\mathrm{LD}_{50}$ value after 24 and $72 \mathrm{~h}$ and 333 and $400 \%$ at 0.1 of $\mathrm{LD}_{50}$ after 24 and $72 \mathrm{~h}$, respectively (Fig. 4 A). In Theba pisana maximum ALT activity was 478 and $500 \%$ at 0.5 of $L_{50}$ value after 24 and $72 \mathrm{~h}$, respectively. Abamectin at 0.2 of $\mathrm{LD}_{50}$ concentration provoked 322 and 333\% ALT activity in Theba pisana after 24 and $72 \mathrm{~h}$ exposure (Fig. $4 \mathrm{~B}$ ).

Increased AST activity $(n=5, p<0.05)$ has been recorded in Eobania vermiculata after abamectin at 0.5 of $\mathrm{LD}_{50}$ concentration after $24(540 \%)$ and $72 \mathrm{~h}(560 \%)$ whereas after 0.2 of $\mathrm{LD}_{50}$ abamectin concentration the AST values at 24 and $72 \mathrm{~h}$ were 400 and $420 \%$ respectively (Fig. 5 A). Abamectin exposure 
to Eobania vermiculata at 0.1 of $\mathrm{LD}_{50}$ concentration increased AST activity after $24(340 \%)$ and $72 \mathrm{~h}(360 \%)$. AST activity in Theba pisana was increased by 500 and $580 \%$ after $0.5 \mathrm{LD}_{50}$ abamectin exposure at 24 and $72 \mathrm{~h}$, respectively (Fig. 5 B). The values of AST activity in Theba pisana after 0.2 of $\mathrm{LD}_{50}$ abamectin concentration were 340 and $360 \%$ after 24 and $72 \mathrm{~h}$,

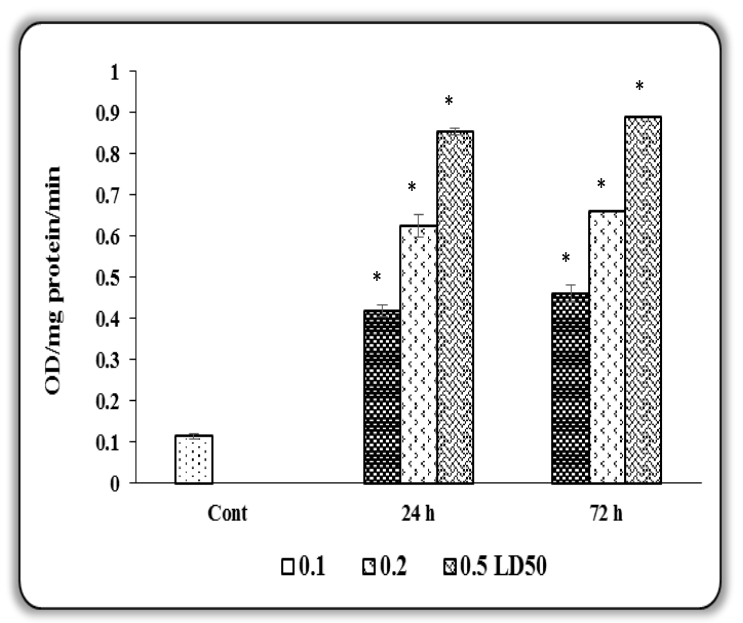

(A)

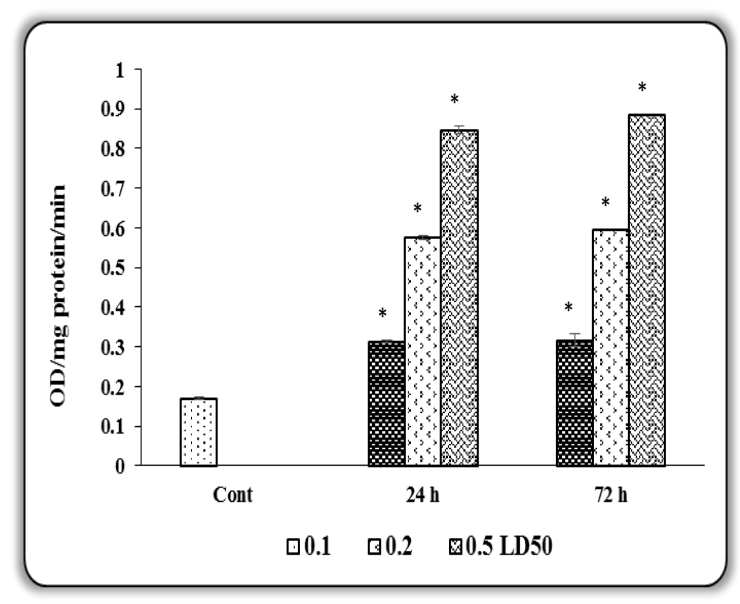

(B)

Fig. 4: Effect of abamectin exposure on the ALT activity in both snails-- (A) Eobania vermiculata (BGS) and (B) Theba pisana (WGS). Each value represents the mean \pm SD of five animals, Asterisk indicates significant difference from control value $(\mathrm{p}<0.05 ; \mathrm{n}=5)$.

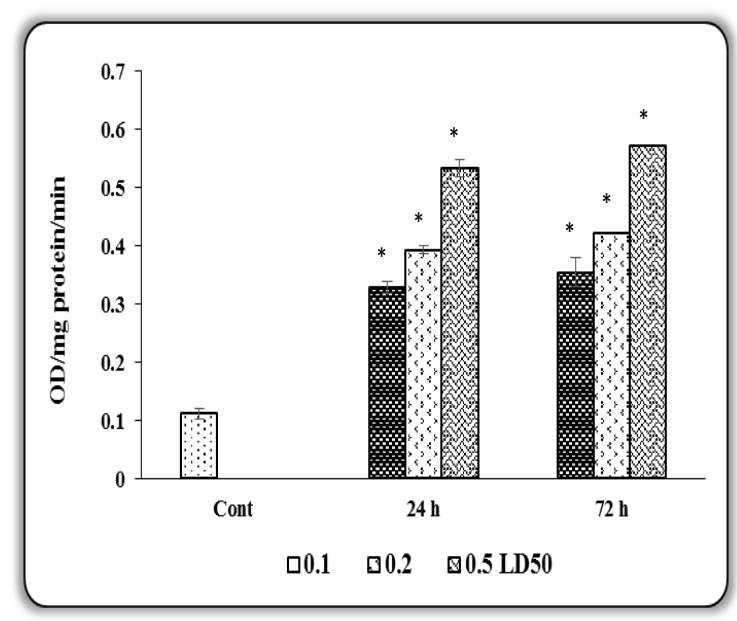

(A)

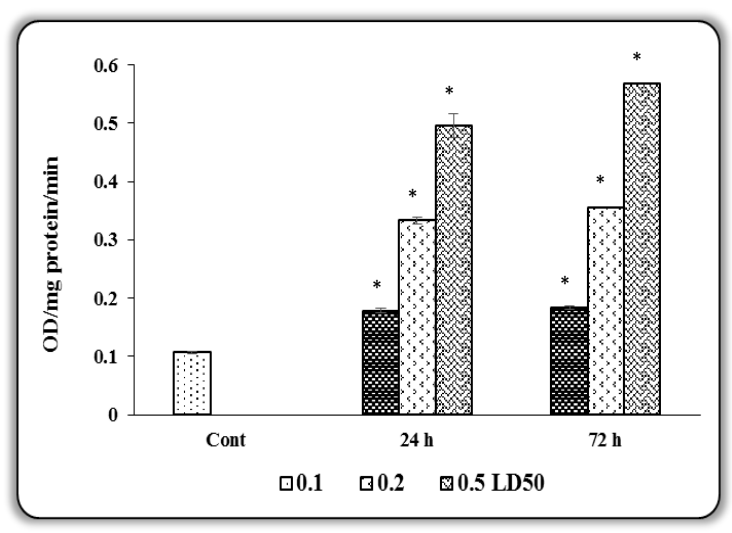

(B)

Fig. 5: Effect of abamectin exposure on the AST activity in both snails-- (A) Eobania vermiculata (BGS) and (B) Theba pisana (WGS). Each value represents the mean \pm SD of five animals, Asterisk indicates significant difference from control value $(\mathrm{p}<0.05 ; \mathrm{n}=5)$.

respectively whereas after 0.1 of $\mathrm{LD}_{50}$ abamectin concentration 180 and 190\% after 24 and $72 \mathrm{~h}$, respectively.

Toxicity of abamectin may affect the hepatocytes. Transaminases (aminotransferases) constitute a group of enzymes that catalyze the interconversion of amino acid in $\alpha$-keto acid by transferring amino group (Moss and Henderson, 1998). Alanine transaminase (ALT) and aspartate transaminase (AST) are present in 
molluscan digestive gland (hepatopancreas) and spill out into general flow when hepatic cells are harmed. The transaminases are acceptable marker of tissue sore. This elevation of ALT and AST has long been used as indicators of damage to hepatic and cardiovascular tissues (Wroblewski and La Due, 1956).

Elevation of AST and ALT of gastropods due to exposure to organic pollutants has been reported in past (Henry et al., 1974; Narvia and Rantamaki, 1997). Previous investigation has demonstrated that abamectin causes increased serum aspartate aminotransferase (AST) (Lowenstein et al., 1996; Hsu et al., 2001). Increased AST, a cytosolic enzyme of the hepatocytes, reflects the increase of plasma membrane permeability resulting from the damage of hepatocytes (Plaa and Hewitt, 1982) and is used to detect liver damage (Klaasen and Eaton, 1991). The results of present study are in conformity with the observations of Ibrahim (2001), Badawy (2010) and Abdelgalil (2011, 2016).

Elevation of the enzyme activity may be due to increased synthesis or decreased catabolism of both enzymes, however, the deviation of both enzyme activities from normal range could lead to biochemical disturbances and alterations of liver tissue and cellular function. Also, elevation of these enzymes is related to increased energy demand as organisms attempt to overcome the toxic effects of pollutants (Reddy and Yellamma, 1991). In the ongoing study, increased activities were observed in both enzymes, especially at higher doses of abamectin.

\section{Conclusion}

This study indicates that abamectin caused acute toxicity to terrestrial snails in terms of provoking adverse effects on enzymes such as GAD, ALT and AST. Thus abamectin could be alternative to molluscicides such as carbamate and/or other toxic pesticides which cause adverse effects to environment and non-target organisms.

\section{References}

Abdallah EAM, Abdelgalil GM, Kassem FA, Asran AA and Abou-Elnasser, HS. (2015) Comparative molluscicidal activity of abamectin and methomyl against Eobania vermiculata (Muller) and Theba pisana (Muller). J. Plant Prot. Path., Mansoura Univ. 6: 1671-1683.

Abdallah EAM, Kassem F A and Kadous EA. (1992) Laboratory and field evaluation of local bait formulations of certain pesticides against mollusk species. J. Pest Control Environ. Sci. 46: 179-192.

Abdallah EAM, Kassem FA, El-Wakil HB and Abo-Bakr Y. (1998) Molluscicidal potentiality of several pesticides against Eobania vermiculata and Theba pisana terrestrial snails. Annals Agric. Sci. Cairo 1: 263-276.

Abdelgalil GM. (2011) Integrated control of economic pulmonata species. Ms. Sci. Thesis of Agric. Faculty. Alex. Univ. Egypt.

Abdelgalil GM. (2016) Molluscicidal activity and biochemical studies of some pesticides against terrestrial snails. Ph. D. Thesis of Agric. Faculty. Alex. Univ. Egypt.

Abdelgalil GM, Abou-Elnasr HS, Khalil MS, Abouhamer MS, Osman AM and Abdallah EAM. (2018) Molluscicidal toxicity of abamectin against Eobania vermiculata and Theba pisana in vivo and the estimation of GABA-Transaminase activity by HPLC. J. Biopest. 11: 161-168.

Abdelmonem MK. (2016) Impact of methomyllannate on physiological parameters of the land snail Eobania vermiculata. J. Basic Appl. Zool. 74:1-7.

Abo-Bakr Y. (1997) Toxicological and enviromental studies on some terrestrial gastropods. Ms. Sci. Thesis of Agric. Faculty. Alex. Univ. Egypt.

Abo-Bakr Y. (2004) Reproductive, hematological and molecular changes in Theba pisana and Biomphlaria alexandrina as target or non-target 
organisms for pesticides. Ph. D. Thesis, Alex. Univ., Egypt.

Abou-Taleb HK, Saad ASA, Mesbah HA, Abdel Rahman SM and El-Deeb DA. (2009) Interaction of emamectin benzoate with GABA neurotransmitter and glutamic acid concentrations and acetylcholinesterase activity of laboratory and field strains of cotton leaf worm larvae. Egypt. J. Agric. Res. 87:135-149.

Allen JC and Griffiths R. (1984) Reversed-phase highperformance liquid chromatographic method for determination of brain glutamate decarboxylase suitable for use in kinetic studies. J. Chromatography B: Biomed. Sci. Appl. 336: 385391.

Badawy NBS. (2010) Toxicological and biochemical studies of some conventional pesticides. Ph. D. thesis of Agric. Faculty. Alex. Univ. Egypt.

Bai SH and Ogbourne S. (2016) Eco-toxicological effects of the avermectin family with a focus on abamectin and ivermectin. Chemosphere 154: 204-214.

Bedair AF. (2010) Toxicological and biochemical interaction of some pesticides. Ph. D. Thesis. Fac. Agric. Alex. Univ. Egypt.

Burg RW, Miller BM, Baker EE, Birnbaum J, Currie SA, Hartman R, Kong Y L, Monaghan RL, Olson G, Putter I, Tunac JB, Wallick H, Stapley EO, Oiwa R and Omura S. (1979) Avermectins, new family of potent anthelmintic agents: producing organism and fermentation. Antimicrob. Agents Chemother. 15: 361-367.

Campbell WC. (1989) Ivermectin and abamectin. Springer-Verlag, New York, USA, p. 363.

Campbell WC and Benz GW. (1984) Ivermectin: a review of efficacy and safety. J. Vet. Pharmacol. Ther. 7: 1-16.

Cooke RC and Gelperin A. (1988) Distribution of GABA-like immunoreactiveneurones in the slug Limax maximus. Cell Tissue Res. 253: 7741.

El-Okda MMK. (1979) Land snails of economic importance at Alexandria region with some notes on the morphological features, classification, economic damage and population on the ornamental plants. Agric. Res. Rev. 1:125-131.

Gathwaite DG and Thomas MR. (1996) The usage of molluscicides in agriculture and horticulture in Great Britain over the last 30 years. In: Henderson, British Crop Protection Council, Farnham, pp. 39-46.
Godan D. (1983) Pest slugs and snails, biology and control. Springer Verlag- Berlin, Heidelberg. pp. 445.

He L, Gao X, Wang J, Zhao Z and Liu N. (2009) Genetic analysis of abamectin resistance in Tetranychus cinnabarinus. Pesticide Biochem.y Physiol. 95: $147-151$

Henry RJ, Cannon DC and Winkleman JW. (1974) Clinical Chemistry, Principles and Techniques. Harper and Row, 2nd ed.

Hernadi L. (1994) Distribution and anatomy of GABAIike immunoreactive neurons in the central and peripheral nervous system of the snail Helix pomatia L. Cell Tissue Res. 227: 189-198.

Hsu Dur-Zong; Hsu Ching-Hung; Huang Bu-Miin and Ming-Yie L. (2001) Abamectin effects on aspartate aminotransferase and nitric oxide in rats. Toxicology 165: 189-193

Huang J and Casida JE. (1997) Avermectin B1a binds to high- and low-affinity sites with dual effects on the $\gamma$-aminobutyric acid-gated chloride channel of cultured cerebellar granule neurons, J. Pharmacol. Exp. Ther. 281: 261-266.

Hussein MA and Sabry AH. (2019) Assessment of some new pesticides as molluscicides against the adult and eggs of chocolate banded snail, Eobania vermiculata. Bull Natl Res Cent 43: 75. https://doi.org/10.1186/s42269-019-0118-6

Ibrahim HA. (1995) Natural extracts as tools for pest control. Ms. Sc. Thesis. Fac. Agric. Alex. Univ., Egypt.

Ibrahim HA. (2001) Toxicological and biochemical studies of natural pesticides against certain economic pests. Ph. D. thesis of Agric. Faculty. Alex. Univ. Egypt.

Kane NS, Hirschberg BQ, Hunt D, Thomas B, Brochu R, Ludmerer SW, Zheng YC, Smith M, Arena JP, Cohen CJ, Schmatz D, Warmke J and Cully DF. (2000) Drug-resistant Drosophila indicate glutamate-gated chloride channels are targets for the antiparasitics nodulisporic acid and ivermectin. Proc. Natl. Acad. Sci. USA 97: 1394913954.

Kass IS, Wang CC, Walrond JP and Stretton AOW. (1980) Avermectin B1a, a paralyzing anthelimenic that affects interneurons in Ascarias suum. Proc. Natl. Acad. Sci. USA. 77: 6211-6215.

Kass IS, Stretton AOW and Wang CC. (1984) The effects of avermectin and drugs related to acetylcholine and 4-aminobutyric acid on 
neurotransmission in Ascaris suum. Mol. Biochem. Parasitol. 13: 213-225.

Kassab A and Daoud H. (1964) Notes on the biology and control of land snails of economic importance in the U. A. R. Agric. Res. Rev. 42: 77-98.

Khalil MS and Darwesh DM. (2019) Avermectins: The promising solution to control plant parasitic nematodes. J. Plant Sci. Phytopathol. 3: 81-85.

Klaassen CD and Eaton DL. (1991) Principles of toxicology. In: Toxicology, (eds.) Amdur MO, Doull J and Klaassen CD. $4^{\text {th }}$ edition, New York: McGrawHill, Inc., pp. 12-49.

Lasota JA and Dybas RA. (1991) Avermectins, a novel class of compounds implications for use in arthropod pest control. Annu. Rev. Entomol. 36: 91-117.

Lglesias J, Jose C and Castro R. (2003) The effects of reported applications of the molluscicide metaldehyde and biocontrol nematodes Phasmarhabditis hermaphrodita on molluscs, earthworm, nematodes, acarids and collembolans: a two year study in north west spain. Pest manag. Sci. 59: 1217-1224.

Lowenstein M, Loupal G, Baumgartner W and Kutzer E. (1996) Histology of the skin and determination of blood and serum parameters during the recovery phase of sarcoptic manage in cattle after avermectin (Ivomec) treatment. Appl. Parasitol. 37: 77-86.

Mohamed MAM. (1995) Toxicological studies on pulmonata species. Ms. Sci. Thesis of Agric. Faculty. Alex. Univ. Egypt.

Moreira RA, de Araujo GS, Silva ARRG, Michiel Adriaan D, Odete R, Amadeu MVMS and Susana L. (2020) Effects of abamectin-based and difenoconazole-based formulations and their mixtures in Daphnia magna: a multiple endpoint approach. Ecotoxicology. doi.org/10.1007/ s10646-020-02218-z.

Moss DW and Henderson AR. (1998) Enzimas. In: Tietz Fundamentos de Química Clínica (eds) Burtis CA and Ashwood ER, 4th ed., Guanabara Koogan, Rio de Janeiro, p. 275-325.

Narvia M and Rantamaki,P. (1997) Aminotransferases in the bivalve mollusk Mytilus edulis L. and short term effects of crude oil in brackish water. J. Biomarkers 2: 253-258.
Ostlind SC and Long R. (1979) Insecticidal activity of the antiparasitic avermectins. Vet. Rec. 105: 168173.

Plaa GL and Hewitt WR. (1982) Detection and evaluation of chemically induced liver injury. In: Principles and Mehtods of Toxicology (ed) Hayes W. Raven Press, New York, pp. 407-445.

Reddy AT and Yellamma K. (1991) Perturbations in carbohydrate metabolism during cypermethrin toxicity in fish, Tilapia mossambica. Biochem. Int. 23: 633-638.

Reitman S and Frankel S. (1957) Glutamic - pyruvate transaminase assay by colorimetric method. Am. J. Clin. Path. 28: 56.

Rossetti V and Lombard A. (1996) Determination of glutamate decarboxylase by high-performance liquid chromatography. J. Chrom. B 681: 63-67.

Strong L and Brown TA. (1987) Avermectins in insect control and biology. Bull. Entomol. Res. 77: 357-389.

Walker RJ. (1986) Transmitters and modulators. In: Mollusca, Neurobiology and Behaviour, (ed) Willows AOD Part 2, Vol. 9. pp. 279-485.

Westcott JD, Hammell KL and Burka JF. (2004) Sea lice treatments, management practices and sea lice sampling methods on Atlantic salmon farms in the Bay of Fundy, New Brunswick, Canada. Aqua. Res. 35: 784-792.

Wroblewski F and Ladue JS. (1956) Serum glutamic pyruvic transaminase in cardiac with hepatic disease. Proc. Soc. Exp. Biol. Med. 91: 569-571.

Wu QJ, Zhang WJ and Xu B Y. (1981) Biological fitness of sensitivity and avermectins resistance in Plutella xylostella. Chinese J. Pest. Sci. 3: 23-28.

Yamazaki J, Matsumoto $\mathrm{K}$, Ono $\mathrm{H}$ and Fukuda $\mathrm{H}$. (1989) Macrolide compounds, ivermectin and milbemycin D, stimulate chloride channels sensitive to GABAergic drugs in cultured chick spinal neurons. Comp. Biochem. Physiol. C 93: 97-104.

Yarovsky PJ and Carpenter DO. (1978) Receptors fi r gamma-aminobutiric acid (GABA) on Aplysia neurons. Brain Res. 144: 75-94.

Young AG and Wilkins MR. (1989) The response of invertebrate acetylcholinesterase to molluscicides. Monograph British Crop Protection Council 41: 121-128. 